\title{
Foreign Ownership and Commercial Banks' Performance in Emerging Market Countries---Evidence from the BRICS
}

\author{
Zhong-zheng Zhang ${ }^{1}$, Xue-mei Yuan ${ }^{2}$ and Su-ling Feng ${ }^{2}$ \\ ${ }^{1}$ The Postgraduate Student in School of Economics University of Jinan, Shandong Province, China \\ ${ }^{2}$ School of Economics University of Jinan, Shandong Province, China \\ se_yuanxm@ujn.edu.cn,331872725@qq.com
}

\begin{abstract}
Using data from 2004 to 2013, we investigate the effects of foreign ownership on commercial banks' performance for "BRICS" countries in a panel consisting of 50 banks 500 observations. Applying DEA model, we compute sample banks' efficiency. Conclusions of regression analysis show that foreign ownership of commercial banks has a significant positive effect on their performance. But this positive effect is limited and will be affected by the size of commercial banks. The larger commercial bank is, the smaller foreign ownership's positive impact on its performance will be
\end{abstract}

Index Terms - commercial banks; foreign ownership; performance; emerging market countries

\section{Introduction}

In recent years, China gradually opening up the banking sector has attracted a lot of foreign capital into the domestic commercial banks. China Banking Regulatory Commission published a new regulation in December 2003 in order to further relax the policy of the entry of foreign ownership. It sped up the pace of opening in banking sector of China. The entry of foreign ownership has had a great impact on the domestic banks' performance. At the same time, some foreign strategic investors sold shares to make profits after lock-up period. It improved the operational risks faced by Chinese commercial banks. In view of this situation, many scholars began to doubt the role of foreign ownership of commercial banks in China. In this paper, we select a few of representative emerging market countries, including China, to study the impact of foreign ownership on commercial banks' performance. Through this study, we hope to provide a reference for the Chinese government to further develop the policy of the entry of foreign ownership.

\section{Literature Review}

Academic mainstream view is that the impact of foreign ownership on commercial banks' performance is positive. Bonin, Hasan and Paul's (2005) research in 11 emerging market countries suggests that foreign banks have better performance than the other banks, especially when they have strategic foreign investment. Using the data of 80 countries and regions from 1988 to 1995 , Classens (2001) studies the impact of foreign ownership on domestic commercial banks' revenue and cost. He finds that the performance of the domestic banks has been improved with the entry of foreign ownership. Moreover, Hasan and Marton (2003) also find that foreign ownership will promote the entire banking system performance. In a recent study, Houda Arouri (2014) uses the value of Tobin's $\mathrm{Q}$ and the market value as the indicators to measure the performance of 58 banks in GCC countries. The result shows that equity from foreign, family and institutional investors all have significant positive impact on the performance of commercial banks.

In contrast, some scholars believe that foreign ownership is not conducive to improving the performance of banks. Clarke's (2005) study shows that in the short term, banks' performance with foreign ownership is lower than those without. Levine (2001) points out that the domestic banks' profitability will decline with the entry of foreign ownership. Uiboupin's (2005) study in 10 countries of Central and Eastern Europe finds that foreign ownership and local commercial banks' interest income, non-interest income and profits are negatively correlated. It also promotes local banks' short-term total cost and increases competition in their banking sectors.

In addition to the linear relationship, some studies have reached different points of view. With the data of 990 banks in 48 countries, Hermes and Lensink (2003) prove that the curve of the relationship between foreign ownership and local banks' interest margin and operating cost is like inverted "U". Lang and Raymond (2002) use the return on assets, return on equity and the net profit margin to measure the performance of commercial banks. Their research finds that these variables and bank's ownership structure have no correlation. The introduction of foreign ownership can not make commercial banks' performance improvements. Alfaro and Xiaoyang Chen (2012) compare the role of foreign ownership during the crisis with non-crisis periods. Their conclusion is that unlike the crisis, the impact of foreign ownership in commercial banks during non-crisis is not obvious.

\section{Efficiency Measurement}

A. Method

Data Envelopment Analysis (DEA) is one kind of the frontier analysis methods. The so-called frontier analysis method is to select the efficient frontier banks to build a efficient frontier. Then it can get one bank's efficiency by measuring the degree of deviation between the bank and efficient frontier. Efficient frontier here is the bank with the 
best efficiency under the given technical conditions and exogenous market conditions. This bank is not the best one in reality, but in theory.

DEA created in 1978 by Charnes, Cooper and Rhodes. It is a data analysis method that uses mathematical programming models to evaluate the Decision Making Units (DMU) with multiple input and output indicators, in order to determine the relative effectiveness between them. It has been widely used to measure business performance.

\section{B. Indicators and Samples}

During the process of DEA, the key is to determine input and output indicators. In this article, based on the characteristics of sample banks and data availability, we select total deposits, total operating expenses and fixed assets as input indicators, and interest income and other operating income as output indicators.

According to our research purpose, this article selects "BRICS" (Brazil, Russia, India, China and South Africa) as representative emerging market countries for the study. In these five countries, according to the size, whether have foreign equity and data availability, we select 10 banks in each one as the sample banks. We define the scope of the study period from 2004 to 2013. The data is from Bankscope database and each bank's annual reports.

\section{Results of Measurement}

TABLE 1 Mean Efficiency Values of Banks in Each Country

\begin{tabular}{|c|c|c|c|c|c|c|}
\hline \multicolumn{2}{|c|}{} & Brazil & Russia & South Africa & India & China \\
\hline \multirow{3}{*}{2004} & TE & 0.71 & 0.32 & 0.57 & 0.53 & 0.31 \\
\cline { 2 - 7 } & PTE & 0.76 & 0.41 & 0.8 & 0.66 & 0.51 \\
\cline { 2 - 7 } 2005 & SE & 0.91 & 0.87 & 0.71 & 0.84 & 0.66 \\
\hline \multirow{3}{*}{2006} & TE & 0.41 & 0.39 & 0.46 & 0.32 & 0.38 \\
\cline { 2 - 7 } & PTE & 0.45 & 0.55 & 0.67 & 0.43 & 0.52 \\
\cline { 2 - 7 } & SE & 0.74 & 0.64 & 0.65 & 0.74 & 0.59 \\
\hline & TE & 0.63 & 0.33 & 0.47 & 0.4 & 0.53 \\
\cline { 2 - 7 } & PTE & 0.8 & 0.63 & 0.63 & 0.51 & 0.66 \\
\hline \multirow{3}{*}{2007} & SE & 0.75 & 0.59 & 0.7 & 0.86 & 0.66 \\
\cline { 2 - 7 } & TE & 0.63 & 0.27 & 0.41 & 0.26 & 0.65 \\
\cline { 2 - 7 } & PTE & 0.86 & 0.52 & 0.74 & 0.37 & 0.71 \\
\hline \multirow{3}{*}{2008} & SE & 0.73 & 0.63 & 0.56 & 0.69 & 0.88 \\
\cline { 2 - 7 } & TE & 0.75 & 0.28 & 0.4 & 0.29 & 0.55 \\
\cline { 2 - 7 } & PTE & 0.92 & 0.58 & 0.72 & 0.37 & 0.71 \\
\hline \multirow{3}{*}{2009} & SE & 0.82 & 0.52 & 0.58 & 0.7 & 0.78 \\
\cline { 2 - 7 } & TE & 0.83 & 0.42 & 0.38 & 0.3 & 0.48 \\
\cline { 2 - 7 } & PTE & 0.87 & 0.7 & 0.73 & 0.44 & 0.58 \\
\hline \multirow{3}{*}{2010} & SE & 0.95 & 0.62 & 0.48 & 0.62 & 0.64 \\
\cline { 2 - 7 } & PTE & 0.77 & 0.45 & 0.37 & 0.36 & 0.44 \\
\cline { 2 - 7 } & SE & 0.87 & 0.68 & 0.69 & 0.50 & 0.55 \\
\hline \multirow{3}{*}{2011} & TE & 0.72 & 0.48 & 0.48 & 0.64 & 0.70 \\
\cline { 2 - 7 } & PTE & 0.87 & 0.66 & 0.65 & 0.55 & 0.51 \\
\cline { 2 - 7 } & SE & 0.81 & 0.77 & 0.49 & 0.67 & 0.75 \\
\hline \multirow{3}{*}{2012} & TE & 0.51 & 0.42 & 0.52 & 0.35 & 0.54 \\
\cline { 2 - 7 } & PTE & 0.68 & 0.54 & 0.7 & 0.45 & 0.59 \\
\cline { 2 - 7 } & SE & 0.73 & 0.73 & 0.73 & 0.68 & 0.85 \\
\cline { 2 - 7 } & PTE & 0.31 & 0.44 & 0.34 & 0.22 & 0.46 \\
\cline { 2 - 7 } & SE & 0.46 & 0.78 & 0.61 & 0.28 & 0.58 \\
\hline & & & & & 0.63 & 0.84 \\
\hline
\end{tabular}

With the data of sample banks' input and output indicators, we measure sample banks' efficiency by DEAP 2.1 software. At first, we use CCR model to measure their technology efficiency (TE). Because CCR model is based on the assumption of the same size, which is not true in the fact. So we further use VRS model based on the assumption of variable size to calculate the pure technical efficiency (PTE) of sample banks. Finally, we calculate their size efficiency (SE) by a formula, TE=PTE:SE. Table 1 shows the mean efficiency values of each country.

\section{Regression Analysis}

\section{A. Variables}

In the model, the dependent variables are efficiency values of sample banks while the explanatory variable is the proportion of foreign ownership. In terms of the control variables, we select the GDP growth rate (GDP) and the weighted average interest margin (IM) as the control variables on country's macroeconomic level, while the natural logarithm of total assets (lnTA), the ratio of liabilities and equity (EL) and overheads $(\mathrm{OH})$ as the control variables on bank level. The data of bank-level variables is from Bankscope database, and the data of country-level variables is from EUI Countrydata database.

TABLE 2 Variable Description

\begin{tabular}{|c|c|c|c|}
\hline & Variable name & Abbreviation \\
\hline \multirow{3}{*}{\multicolumn{2}{|c|}{ Dependent variable }} & Technology efficiency & $\mathrm{TE}$ \\
\hline & & Pure technical efficiency & PTE \\
\hline & & Size efficiency & $\mathrm{SE}$ \\
\hline \multicolumn{2}{|c|}{ Explanatory variable } & Proportion of foreign ownership & FOR \\
\hline \multirow{5}{*}{$\begin{array}{c}\text { Control } \\
\text { variable }\end{array}$} & \multirow{3}{*}{$\begin{array}{l}\text { Bank } \\
\text { level }\end{array}$} & The natural logarithm of total assets & $\operatorname{lnTA}$ \\
\hline & & The ratio of liabilities and equity & EL \\
\hline & & Overheads & $\mathrm{OH}$ \\
\hline & \multirow{2}{*}{$\begin{array}{c}\text { Country } \\
\text { level }\end{array}$} & GDP growth rate & GDP \\
\hline & & The weighted average interest margin & IM \\
\hline
\end{tabular}

\section{B. Models}

We follow the idea which Claessens (2001) proposed when build models. First of all, we make linear regression analysis models with the whole panel data of sample banks to estimate the overall trend of relationship between foreign ownership and banks' performance.

$$
\begin{aligned}
T E_{i, t}= & \alpha_{i}+\beta_{1} F O R_{i, t}+\beta_{2} \ln T A_{i, t}+\beta_{3} E L_{i, t}+\beta_{4} O H_{i, t}+\beta_{5} G D P_{i, t} \\
& +\beta_{6} I M_{i, t}+\omega_{i, t} \\
P T E_{i, t} & =\alpha_{i}+\beta_{1} F O R_{i, t}+\beta_{2} \ln T A_{i, t}+\beta_{3} E L_{i, t}+\beta_{4} O H_{i, t}+\beta_{5} G D P_{i, t} \\
& +\beta_{6} I M_{i, t}+\omega_{i, t} \\
S E_{i, t}= & \alpha_{i}+\beta_{1} F O R_{i, t}+\beta_{2} \ln T A_{i, t}+\beta_{3} E L_{i, t}+\beta_{4} O H_{i, t}+\beta_{5} G D P_{i, t} \\
& +\beta_{6} I M_{i, t}+\omega_{i, t}
\end{aligned}
$$

Where $\mathrm{i}=1,2, \cdots \cdots, \mathrm{N}, \mathrm{t}=1,2, \cdots \cdots, \mathrm{T}$.

Then, in order to examine whether there is an optimal proportion of foreign ownership to make commercial banks' performance achieve optimal, in the linear regression models 
above, we introduce a squared term variable $\mathrm{FOR}^{2}$ to build nonlinear regression models. Our models are as follow:

$$
\begin{aligned}
T E_{i, t}= & \alpha_{i}+\beta_{1} F O R_{i, t}+\beta_{2} F O R_{i, t}{ }^{2}+\beta_{3} \ln T A_{i, t}+\beta_{4} E L_{i, t}+\beta_{5} O H_{i, t} \\
& +\beta_{6} G D P_{i, t}+\beta_{7} I M_{i, t}+\omega_{i, t} \\
P T E_{i, t} & =\alpha_{i}+\beta_{1} F O R_{i, t}+\beta_{2} F O R_{i, t}{ }^{2}+\beta_{3} \ln T A_{i, t}+\beta_{4} E L_{i, t}+\beta_{5} O H_{i, t} \\
& +\beta_{6} G D P_{i, t}+\beta_{7} I M_{i, t}+\omega_{i, t} \\
S E_{i, t}= & \alpha_{i}+\beta_{1} F O R_{i, t}+\beta_{2} F O R_{i, t}{ }^{2}+\beta_{3} \ln T A_{i, t}+\beta_{4} E L_{i, t}+\beta_{5} O H_{i, t} \\
& +\beta_{6} G D P_{i, t}+\beta_{7} I M_{i, t}+\omega_{i, t}
\end{aligned}
$$

Finally, we study whether the size of the commercial banks will affect the impact of foreign ownership on performance by adding a interaction item FOR $\cdot \ln T A$ in (2).

$$
\begin{aligned}
P T E_{i, t} & =\alpha_{i}+\beta_{1} F O R_{i, t}+\beta_{2} \ln T A_{i, t}+\beta_{3} F O R_{i, t} \bullet \ln T A_{i, t}+\beta_{4} E L_{i, t} \\
& +\beta_{5} O H_{i, t}+\beta_{6} G D P_{i, t}+\beta_{7} I M_{i, t}+\omega_{i, t}
\end{aligned}
$$

\section{Regression Results}

1) Linear Regression Analysis

we use Stata 12.0 software to analysis the regression models above. And the results of the first three regression models are given in Table 3.

TABLE 3 Results of Linear Regression Models

\begin{tabular}{|c|c|c|c|}
\hline & Model 1 & Model 2 & Model 3 \\
\hline \multirow{2}{*}{ Constant Term } & $-0.5219^{*}$ & 0.0445 & 0.0991 \\
& $(0.3260)$ & $(0.3366)$ & $(0.2886)$ \\
\hline \multirow{2}{*}{ FOR } & $0.0028^{* *}$ & $0.0028^{* *}$ & $0.0019^{*}$ \\
& $(0.0012)$ & $(0.0012)$ & $(0.0011)$ \\
\hline \multirow{2}{*}{$\operatorname{lnTA}$} & $0.0716^{* *}$ & $0.0433^{*}$ & 0.0311 \\
& $(0.0286)$ & $(0.0295)$ & $(0.0253)$ \\
\hline \multirow{2}{*}{ EL } & 0.0006 & 0.0011 & 0.0001 \\
& $(0.0013)$ & $(0.0014)$ & $(0.0012)$ \\
\hline \multirow{2}{*}{ OH } & $-0.0001^{* *}$ & $-0.0001^{*}$ & 0.0001 \\
& $(0.0000)$ & $(0.0000)$ & $(0.0000)$ \\
\hline \multirow{2}{*}{ GDP } & 0.0041 & 0.0018 & $0.0060^{*}$ \\
& $(0.0050)$ & $(0.0052)$ & $(0.0045)$ \\
\hline \multirow{2}{*}{ IM } & $0.0196^{* * *}$ & $0.0087^{*}$ & $0.0203^{* * *}$ \\
& $(0.0057)$ & $(0.0059)$ & $(0.0051)$ \\
\hline F & 3.66 & 1.95 & 4.04 \\
\hline P & 0.0015 & 0.0008 & 0.0006 \\
\hline
\end{tabular}

$*, * *$ and $* * *$ indicate significance levels of 10,5 and $1 \%$, respectively.

As table 2 shows, $\mathrm{F}$ values in three models have all passed the test of significance. FOR have passed significant test too, indicating that these models are reasonable reflection of the relationship between foreign ownership and commercial banks' performance. The result of the linear regression models shows that, the relationship between foreign ownership and commercial banks' performance is positive. In other words, the introduction of foreign ownership will have a positive effect on commercial banks' performance improvement. The conclusion we come to is consistent with the most current research in this area, e.g. Classens (2001), Bonin (2005) et al.

2) Nonlinear Regression Analysis

We give the results of the two kinds of nonlinear regression models in Table 4.
TABLE 4 Results of Nonlinear Regression Models

\begin{tabular}{|c|c|c|c|c|}
\hline $\begin{array}{c}\text { Constant } \\
\text { Term }\end{array}$ & $\begin{array}{c}-0.5102 \\
(0.3260)\end{array}$ & $\begin{array}{c}0.0650 \\
(0.3357)\end{array}$ & $\begin{array}{c}0.1046 \\
(0.2889)\end{array}$ & $\begin{array}{c}0.0504 \\
(0.3791)\end{array}$ \\
\hline FOR & $\begin{array}{c}0.0056^{* *} \\
(0.0027)\end{array}$ & $\begin{array}{c}0.0077^{* * *} \\
(0.0027)\end{array}$ & $\begin{array}{c}0.0032 \\
(0.0023)\end{array}$ & $\begin{array}{c}0.0187^{* *} \\
(0.0083)\end{array}$ \\
\hline FOR ${ }^{2}$ & $\begin{array}{c}-6.51 \mathrm{E}-05 \\
(2.98 \mathrm{E}-05)\end{array}$ & $\begin{array}{c}-1.02 \mathrm{E}-04^{* *} \\
(3.07 \mathrm{E}-05)\end{array}$ & $\begin{array}{c}-2.65 \mathrm{E}-05 \\
(2.64 \mathrm{E}-05)\end{array}$ & - \\
\hline lnTA & $\begin{array}{c}0.0683^{* *} \\
(0.0287)\end{array}$ & $\begin{array}{c}0.0375 \\
(0.0296)\end{array}$ & $\begin{array}{c}0.0296 \\
(0.0255)\end{array}$ & $\begin{array}{c}0.0451 \\
(0.0342)\end{array}$ \\
\hline FOR・lnT & - & - & - & $-0.0017^{* *}$ \\
$\mathrm{~A}$ & $0.0009)$ \\
\hline EL & $\begin{array}{c}0.0005 \\
(0.0014)\end{array}$ & $\begin{array}{c}-0.5102 \\
(0.3260)\end{array}$ & $\begin{array}{c}0.0001 \\
(0.0012)\end{array}$ & $\begin{array}{c}0.0010 \\
(0.0014)\end{array}$ \\
\hline OH & $\begin{array}{c}-0.0001 * * \\
(0.0000)\end{array}$ & $\begin{array}{c}0.0056^{* *} \\
(0.0027)\end{array}$ & $\begin{array}{c}0.0001 \\
(0.0000)\end{array}$ & $\begin{array}{c}-0.0001 * \\
(0.0000)\end{array}$ \\
\hline GDP & $\begin{array}{c}0.0042 \\
(0.0050)\end{array}$ & $\begin{array}{c}-6.51 \mathrm{E}-05 \\
(2.98 \mathrm{E}-05)\end{array}$ & $\begin{array}{c}0.0061 \\
(0.0045)\end{array}$ & $\begin{array}{c}-0.0040 \\
(0.0053)\end{array}$ \\
\hline IM & $\begin{array}{c}0.0195^{* * *} \\
(0.0057)\end{array}$ & $\begin{array}{c}0.0683 * * \\
(0.0287)\end{array}$ & $\begin{array}{c}0.0202^{* * *} \\
(0.0051)\end{array}$ & $\begin{array}{c}0.0088 \\
(0.0061)\end{array}$ \\
\hline $\mathrm{F}$ & 3.34 & 2.26 & 3.51 & 2.15 \\
\hline P & 0.0018 & $\begin{array}{c}0.0005 \\
(0.0014)\end{array}$ & 0.0011 & 0.0037 \\
\hline
\end{tabular}

$*, * *$ and $* * *$ indicate significance levels of 10,5 and $1 \%$, respectively.

The table above shows that in model $5, \mathrm{FOR}^{2}$ is significant at $5 \%$ significance level, and its coefficient is negative, indicating that pure technical efficiency of commercial banks rises in the first stage and then decreases as inverted "U" shape, with the proportion of foreign ownership growing. The regression equation's extreme appears at $37.89 \%$. As Fig. 1 shows, initially, the curve is inclined to the upper right, and reaches its highest point at $37.98 \%$. However, after this, the curve begins to tilt to the lower right. It indicates that when the proportion of foreign ownership is less than $37.89 \%$, pure technical efficiency of commercial banks continues to improve with foreign ownership, and reaches a maximum value at $37.89 \%$. This is similar to Grigorian's (2002) conclusion that when the proportion of foreign ownership is $30 \%$, it will have the greatest positive effect on commercial banks' performance.

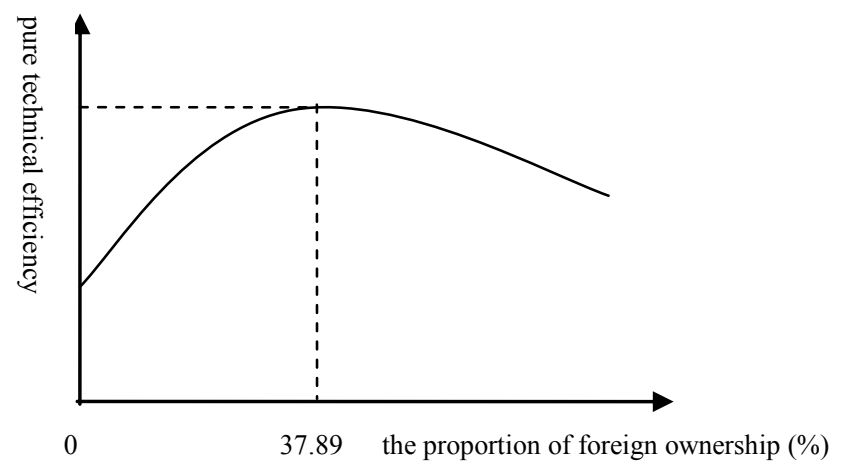

Fig. 1 Curve of the Relationship between the Proportion of Foreign Ownership and Pure Technical Efficiency

Last column of Table 4 shows that individual item FOR and interaction term FOR $-\operatorname{lnTA}$ are all significant at 5\% significance level, indicating that the scale factor plays an 
important role in the impact of foreign ownership on commercial banks' performance. Furthermore, in this model, the coefficient of individual item FOR is positive, while the coefficient of interaction term FOR $\cdot \ln \mathrm{TA}$ is negative. Under the condition of fixed FOR, the greater $\operatorname{lnTA}$ is, the greater negative impact on the dependent variable PTE will it produce. This shows that when the proportion of foreign ownership of commercial banks is given, the positive effect which foreign ownership on performance will be getting smaller and smaller with the size of banks growing. In other words, the larger commercial bank is, the smaller foreign ownership's positive impact on its performance will be.

\section{Conclusion}

This article selects 50 commercial banks in the BRICS to study the performance of commercial banks in the emerging market countries, and the time spans from 2004 to 2013. Firstly, we use the DEA model to measure sample banks' performance, and then, we have the regression analysis. Conclusions show that foreign ownership of commercial banks has a significant positive effect on their performance. The introduction of foreign ownership into commercial banks is in favor of performance improvement. In addition, with the proportion of foreign ownership rising, pure technical efficiency presents a trend of rise first then fall. Its highest point occurs when the proportion of foreign ownership is $37.89 \%$. This shows that the positive effect of the introduction of foreign ownership on commercial banks' performance is limited. Just raising the proportion of foreign ownership can not continue improving the performance of commercial banks.

In this paper, we further study the role of the scale factor of commercial banks in the impact of foreign ownership on the performance. We find that when the proportion of foreign ownership of commercial banks is given, the positive effect which foreign ownership on performance will be getting smaller and smaller with the size of banks growing. According to our conclusion, on the issue of introduction of foreign ownership, commercial banks should make different decisions based on their specific size.

\section{Acknowledgment}

This work was supported by The National Social Science Funds project "The research on foreign direct investment in banking sector of emerging market economies" (Grant No. 11BGJ009) and Shandong Provincial Natural Science Foundation (ZR2012GL01).

\section{References}

[1] Claessens S., Demitgue A. and Huizinga H, "How does Foreign Entry Affect Domestic Banking Market?" Journal of Banking and Finance, vol. 25, pp. 891-911, 2011.

[2] Bonin J.P., Hasan I. and Wachtel P., "Privatization Matters: Bank Efficiency in Transition Countries," Journal of Banking and Finance, vol. 29, pp. 2155-2178, 2005.

[3] Hasan I. and Marton K., "Development and Efficiency of the Banking Sector in a Transitional Economy: Hungarian Experience," Journal of Banking and Finance, vol. 27, pp. 2249-2271, 2003.

[4] Clarke R.G., "The Direct and Indirect Impact of Bank Privatization and Foreign Entry on Access to Credit in Argentina's Provinces," Journal of Banking and Finance, vol. 29, 2005.

[5] Janek Uiboupin, "Short-term Efferts of Foreign Bank Entry on Bank Performance in Selected CEE Countries," Bank of Estonia Working Papers, 2005.

[6] Robert Lensink and Ilko Naaborg, "Does Foreign Ownership Foster Bank Performance?" Applied Financial economics, vol. 17, pp. 881885, 2007.

[7] Hermes and Lensink, "How Does Foreign Entry Affect Domestic Banking Markets," Journal of Banking and Finance, vol. 25, pp. 591712, 2003

[8] Larry H.P. Lang and Raymond W.S., "Bank Ownership Structure and Economic Performance," Journal of Banking and Finance, 2002.

[9] Houda Arouri, "Effect of Board and Ownership Structure on Corporate Performance: Evidence from GCC Countries," Journal of Accounting in Emerging Economies, vol. 1, pp. 117-130, 2014.

[10] Laura Alfaro and Xiaoyang Chen, "Surviving the Global Financial Crisis: Foreign Ownership and Establishment Performance," American Economic Journal: Economic Policy, vol. 3, pp. 30-55, 2012.

[11] Grigorian D. and Manole V., "Determinants of Commercial Bank Performance in Transition: An Application of Data Envelopment Analysis,"World Bank Policy Research Working Paper, 2002. 